\title{
Constructing Human Rights
}

\author{
State Power and Migrant Silence
}

Jaya Ramji-Nogales

This chapter analyzes the role of states in framing the scope and applicability of human rights protections. The limited perspective of the sovereign has constructed a system that, while ostensibly universal, prioritizes the power of the state while erasing the interests of migrants. The chapter argues that this flaw at the conceptual core of human rights contributes to contemporary migration-related challenges and demands radical rethinking.

Responding to the horrors of the Second World War, the project of human rights law described itself as a movement that would extend rights to all people by simple virtue of their humanity. This was a noble cause, but its ambition was hampered by the process and structure of international human rights treaties. Drafted by representatives of states, who were also the central subject and primary enforcer of these laws, multilateral human rights treaties perhaps unsurprisingly maintained the sovereign interest in border control. This profound state prerogative also manifested itself in the content of international human rights law itself - or perhaps more accurately, in human rights law's silences.

Migrants are of course protected by numerous basic international human rights that attach to all people regardless of migration status. Human rights law constrains state behavior with respect to these rights, including the right to life, the right to be free from torture, and the right to freedom of thought and religion. Yet, when it comes to rights that would impinge on the sovereign's ability to control its borders, such as the right to enter into, the right to safe transit to, and even the right to remain in a destination state, international law falls silent.

Destination states in the Global North have expanded their power into that gap, building a variety of mechanisms to keep migrants away from their borders. From the "Pacific Solution" to "Operation Sovereign Borders," Australia has kept its sea borders clear of migrants (see Chapter 4 in this volume). Through agreements with North African and Middle Eastern states such as Libya and Turkey as well as the 
Dublin Regulation, ${ }^{1}$ Europe has attempted to minimize the number of migrants reaching its shores. The United States has used a variety of harsh border control methods in an effort to deter migrants from approaching its southern land border (see Chapter 3 in this volume). Migrants pay the cost of these deterrence and border control programs financially, physically, and emotionally, as they are subject to extortion, exploitation, and abuse during their journeys. Yet these humans are not and will not be deterred from moving, as they seek freedom from harsh conditions in their countries of origin, pursuing the exercise of their human autonomy (see Chapter 6 in this volume). These deterrence policies increasingly encompass measures designed to strip migrants of their human dignity, and come at the cost of degrading the humanity of destination states. ${ }^{2}$

In the contemporary era of widespread anti-immigrant sentiment, it is hard to imagine states ceding power to protect migrants. Nevertheless, a critical analysis of the current structure of human rights law and its consequences points to the possibilities of an approach that takes the voices of migrants into account: a new human rights treaty focused on migrants rather than states. ${ }^{3} \mathrm{~A}$ human rights instrument that fully represents migrant interests is not likely to be signed by any destination states any time soon, but could still be a worthwhile drafting exercise in terms of its expressive function. This instrument might not be law in the traditional sense, but the process would bring together a variety of groups from civil society to corporations to diaspora to transnational families. A representative catalogue of migrants' rights could help to frame the debate, persuade the public, and focus activist energies in lobbying states for change.

\section{THE PROJECT OF HUMAN RIGHTS LAW}

From its inception, international human rights law has represented itself as a project that extends rights to all people by simple virtue of their humanity. Although human

1 Adopted in 2003, the Dublin Regulation determines which member state of the European Union is responsible for adjudicating an asylum seeker's protection claim. The responsibility normally lies with the country where the asylum seeker first entered the EU. European Parliament and Council Regulation (EU) No 604/2013, Establishing the Criteria and Mechanisms for Determining the Member State Responsible for Examining an Application for International Protection Lodged in One of the Member States by a Third-Country National or a Stateless Person (June 26, 2013).

z Bhabha, "Zero Humanity."

3 This treaty would differ from the International Convention on the Protection of the Rights of All Migrant Workers and Members of Their Families in that it would provide rights that are fundamental to protecting undocumented migrants, such as the right to territorial security. International Convention on the Protection of the Rights of All Migrant Workers and Members of Their Families, July 1, 2003, 2220 U.N.T.S. 3; J. Ramji-Nogales, "Undocumented Migrants and the Failures of Universal Individualism" (2014) 47 Vanderbilt Journal of Transnational Law $699-763$ at $722-739$. The treaty would contain much stronger protections for the rights of undocumented migrants than the UN Global Compact for Safe, Orderly, and Regular Migration, which has been widely criticized for failing to make any meaningful changes to existing international law, particularly with respect to protection for undocumented migrants. 
rights law has undoubtedly contributed to a variety of expanded protections for many individuals, it has not fulfilled this original promise. There are of course many reasons for this shortcoming; this chapter focuses on one key factor: the role of sovereigns of the Global North in drafting and enforcing human rights law, and the resultant gaps in its protections.

Contemporary international human rights law, including in its canon treaties such as the Covenant on Civil and Political Rights, the Convention on the Elimination of All Forms of Racial Discrimination, and the Covenant on Economic, Social and Cultural Rights, was drafted in the wake of the Second World War. ${ }^{4}$ The United Nations describes the creation of international human rights law as an effort by the international community to ensure that the human rights abuses perpetrated during the war never occurred again. ${ }^{5}$ However, critical scholarship has described human rights law, which was created contemporaneously with independence movements in the Global South, as a continuation of "colonial ideology and practices" that "represent[ed] Western ideas of the individual, state, and society." 7 In other words, from the start, the project of human rights law portrayed itself as universal while privileging a particular worldview.

The United Nations website describes the Universal Declaration of Human Rights as "a roadmap to guarantee the rights of every individual everywhere." This proclamation leaves open at least one core question about the scope of international human rights: exactly which rights are being guaranteed? The description appears to rely on an unsurfaced assumption that the content of these rights is universally agreed upon, or "[reflecting] a common sense of justice, fairness, and decency." Even if international human rights law was somehow able to locate a set of rights that reflected the moral tenets of the vast and diverse membership of

4 See P. Alston, "Does the Past Matter? On the Origins of Human Rights" (2013) 126 Harvard Law Review 2043-2081 at 2065 (reviewing J. S. Martinez, The Slave Trade and the Origins of International Human Rights Law (New York: Oxford University Press, 2012)) (explaining that "the most common starting point for modern histories of human rights is the United Nations Charter of 1945 and the Universal Declaration of Human Rights of 1948" but suggesting that projects to pinpoint precisely a single origin are flawed).

5 United Nations, "Universal Declaration of Human Rights: History of the Document," www.un .org/en/sections/universal-declaration/history-document/index.html; cf. S. Moyn, The Last Utopia (Cambridge, MA: Harvard University Press, 2010), p. 7.

6 B. Rajagopal, International Law from Below: Development, Social Movements and Third World Resistance (Cambridge: Cambridge University Press, 2003), p. 176; see also J. Reynolds, Empire, Emergency and International Law (Cambridge: Cambridge University Press, 2017), pp. 115-116. But see M. Mazower, No Enchanted Palace: The End of Empire and the Ideological Origins of the United Nations (Princeton, NJ: Princeton University Press, 2009), pp. 94-96.

7 A. Anghie, Imperialism, Sovereignty, and the Making of International Law (Cambridge: Cambridge University Press 2005), p. 254.

8 United Nations, "Universal Declaration of Human Rights."

9 L. Henkin, The Age of Rights (New York: Columbia University Press, 1990), p. 2; see also Universal Declaration of Human Rights, December 10, 1948, United Nations General Assembly Res. $217 \mathrm{~A}(\mathrm{III})$, pmbl. 
humanity, the guarantee also of course relies on states to guarantee these rights to "all members of the human family." ${ }^{\circ}$ It is quickly apparent where this plan might fall short: states are not likely protectors of the humans at the margins of their societies, particularly those who might in the state's view be undesirable. ${ }^{11}$ Undocumented migrants present both of these challenges to the human rights canon: they demand rights that may not be universally accepted and they are generally disfavored by states, who prize the ability to exclude as a manifestation of their sovereign ability to control their territorial borders.

Though the idea of human rights arose much earlier, the evolution of rights in international law has a particular and contingent history that contributed to this gap between the story that human rights law tells about itself and its application on the ground. Anthony Anghie locates the foundations of modern international law in the colonial encounter between the Spanish and Indigenous people in the Americas. ${ }^{12}$ He explains that the doctrine of sovereignty arose from Francisco di Vitoria's struggle to create a legal system that managed relations between these two societies and their disparate cultural orders. ${ }^{13}$ Vitoria created the idea of natural law, which enabled the Spanish to insist that their cultural practices were a universally valid baseline that could and should be enforced both externally and by ensuring that their colonial subjects and others internalized these claims to universality. ${ }^{14}$ In addition, Martti Koskenniemi explains that the Spanish theologians' theoretical approach to universal and individualized rights focused on ensuring horizontal justice between individuals rather than vertical justice between the individual and their community. ${ }^{15}$ Their theories supported territorial notions of sovereignty as well as ownership rights over private property. Koskenniemi describes this preWestphalian international legal regime in terms that are equally apt today, as a "powerful and long-standing type of informal imperial domination that is achieved through a worldwide pattern of acquisition and exchange of private property by which ... formal state policies are also controlled, enabled, or undermined, as befits the global market." 16

In the same way, the fundamental rights conceptualized in the French and American Revolutions promised more than they delivered. The radical move to identifying the people (rather than the crown) as the source of political authority required a natural rights justification that could exist independent of the state. Unfortunately, social and historical realities simply did not match up with the idea

10 Universal Declaration of Human Rights, pmbl.

${ }^{11}$ E. Goffman, Stigma: Notes on the Management of Spoiled Identity (New York: Simon \& Schuster, 1986).

${ }_{12}$ Anghie, Imperialism, p. 15.

${ }^{13}$ Ibid., p. 16.

${ }^{14}$ Ibid., pp. 21-23.

${ }^{15}$ See M. Koskenniemi, "Empire and International Law: The Real Spanish Contribution" (2011) 61 University of Toronto Law Journal 1.

${ }^{16}$ Ibid., at 32. 
that power came from the people, who as a result held inalienable and universal rights. ${ }^{17}$ Statehood was born of armed conflict, not from the inherent authority of the people. These allegedly fundamental rights were narrow in scope and applied only to a select few individuals; they were hardly universal in practice. ${ }^{18}$ And similar to the Spanish theologians, this new approach to rights created a division between the private or economic sphere and the public or political sphere. ${ }^{19}$ Though this change was justified as furthering the interests of all people, on the ground, it established new power relationships that furthered some interests more than others. ${ }^{20}$

It was against this rather flawed backdrop that international human rights law was created. The new treaties drafted in response to the Second World War claimed universality yet extended a politically determined set of rights selectively. For example, the International Covenant on Civil and Political Rights (ICCPR) failed to extend certain key rights to groups such as undocumented migrants. ${ }^{21}$ In particular, human rights law reinforced the Western liberal democratic order by prioritizing individual and political rights over distributive and economic justice. While the ICCPR established binding obligations on its member states and required compliance in the short term, the International Covenant on Economic, Social, and Cultural Rights was characterized as an aspirational document that encouraged member states to make every effort to comply in the long term. ${ }^{22}$ This hierarchy that elevated civil and political rights above economic and social rights offered many eloquent provisions discussing the individual right to equality yet no opportunity to challenge the deep inequalities of global economic order. ${ }^{23}$

International human rights law can be understood as part of a longer historical phenomenon that fundamentally altered the basis for governance, yet entrenched a particular framework for social change that is amenable to economic interests that

${ }^{17}$ N. Stammers, "Human Rights and Power" (1993) 41 Political Studies 70-82 at 72-73.

18 Ibid., at 75 .

19 T. Evans, The Politics of Human Rights (London: Pluto Press, 2005), pp. 15-16.

${ }^{20}$ Ibid., p. 16.

${ }^{21}$ See L. Bosniak, "Human Rights, State Sovereignty and the Protection of Undocumented Migrants under the International Migrant Workers Convention" (1991) 25 International Migration Review 737 at 737 (concluding that "the [ICCPR]'s ability to substantially ameliorate the human rights situation of irregular migrants is significantly constrained by its over-riding commitment to the norms and structures of sovereign statehood").

${ }^{22}$ International Covenant on Civil and Political Rights, December 10, 1984, 999 U.N.T.S. 171, art. 13; International Covenant on Economic, Social and Cultural Rights, December 16, 1966, G.A. Res. 2200 (XXI), U.N. Doc. A/6316.

${ }^{23}$ Evans, The Politics of Human Rights, pp. 43-44; see A. Kirkup and T. Evans, "The Myth of Western Opposition to Economic, Social, and Cultural Rights?: A Reply to Whelan and Donnelly" (2009) 31 Human Rights Quarterly 221-238 at 226-232 (discussing the privatesector-fueled backlash to the idea of including social and economic rights in any list of universal rights). 
seek to subjugate rather than emancipate. ${ }^{24}$ Human rights law's claims to universality mask political choices that prioritize certain interests over others. The coverage of these rights is narrower than the label "universal" might suggest; different levels of protection are allocated to more and less powerful individuals. Individual and political rights are prized while structural and economic harms are obscured. All the while, the language of universal individualism can be used to camouflage the perpetuation of extant power structures.

\section{THE HUMAN RIGHTS OF MIGRANTS}

Undocumented migrants present a particularly illuminating case study through which to examine the limitations of international human rights law. Though they are on paper accorded the same fundamental rights provided to all human beings, undocumented migrants are much less likely to be able to access these protections on the ground due to their precarious status. Moreover, the rights that are most important to the undocumented - safe transit, entry, and to remain - are found nowhere in the canon of human rights law. ${ }^{25}$

Though human rights law appears to provide universal protections, the obstacles to enforcing those rights means that vulnerable populations face limited access to those rights in practice. Migrants are particularly vulnerable in transit, suffering harms ranging from murder to brutal sexual assault to extreme financial extortion. ${ }^{26}$ Even after undocumented migrants are able to enter the territory of their destination, they are targets for violence and exploitation at the hands of a variety of actors. The undocumented are rendered vulnerable through their immigration status; even if they know that there is a legal remedy for the harms they suffer, they may be unable to report these abuses to and seek protection from local authorities because they fear deportation. ${ }^{27}$ Many of the undocumented migrate to seek employment,

24 See, e.g., U. Baxi, "Voices of Suffering and the Future of Human Rights" (1998) 8 Transnational Law and Contemporary Problems 125-70 at 163-64 ("This new [trade-related, market friendly, human rights] paradigm reverses the notion that universal human rights are designed for the dignity and well being of human beings and insists, instead, upon the promotion and protection of the collective rights of global capital in ways that 'justify' corporate well-being and dignity over that of human persons."); Rajagopal, International Law from Below, p. 246 (describing the "uncritical acceptance of the counter-sovereignty liberal rights rhetoric, without examining the socioeconomic and cultural foundations of rights and sovereignty" as one of two weaknesses that "have greatly reduced the transformatory potential of international human-rights discourse, and instead made it into a handmaiden of particular constellations and exercises of power").

25 I should note here that by "international human rights law" I mean to discuss only multilateral human rights treaties. Regional human rights law such as the American Convention on Human Rights and the European Convention on Human Rights offer some contestation around a few of these rights.

${ }_{26}$ invisiblesfilms, www.youtube.com/user/invisiblesfilms.

${ }^{27}$ See, e.g., P. Bouckaert, Prohibited Persons: Abuse of Undocumented Migrants, Asylum-Seekers, and Refugees in South Africa (New York: Human Rights Watch, 1998); J. J. Lee, "Redefining 
often finding jobs available to them only in dirty, degrading, and dangerous sectors. When their employers refuse to pay them, these migrants may fear that identifying themselves to law enforcement will result in their deportation; indeed, employers can prey on these fears and threaten to call migration control if migrants attempt to assert their rights. Some migrants brave enough to report these and other violations to law enforcement are then exploited and abused by government actors. Undocumented migrants belonging to relatively isolated linguistic groups face even greater obstacles to understanding and accessing their rights, and can be preyed upon by members of their community, who may demand usurious fees to provide them with faulty or obvious information.

Human rights law is not responsive to the needs of these migrants. Though empirical studies of population preferences are hard to come by, it seems fairly safe to assume that undocumented migrants would prize the right to enter their destination state lawfully, the right to travel safely to that state, and the right to remain safely once on the territory of that state. The first right, to entry at will, is not accorded to any set of migrants, even refugees, who otherwise benefit from preferential treatment. Though the Universal Declaration of Human Rights envisioned a right to asylum that would have enabled refugees to enter any country to seek protection, that aspirational provision failed to find its way into any multilateral human rights treaty. ${ }^{28}$ The right to travel safely is similarly absent from human rights law. Though migrants in transit are in theory protected by international human rights treaties signed by transit countries, they face perhaps even greater challenges in enforcing those rights than undocumented migrants in the host state because of the increased level of vulnerability implicated in travel. More importantly, human rights law does not authorize migrants to access safe carriers, relegating them to dangerous journeys by foot, in cramped and often airless trunks and shipping crates, and on top of trains. Finally, the plain text of human rights treaties does not offer undocumented migrants the right to remain in their host state. Treaty interpretive bodies have refused to read that right into any of the multilateral human rights treaties. ${ }^{29}$

the Legality of Undocumented Work" (2018) 106 California Law Review 1617-1656, at 1624-1626; M. J. Gibney, "Outside the Protection of the Law: The Situation of Irregular Migrants in Europe" (2000) Refugee Studies Center, Working Paper No. 6, p. 21; "The Law Was Against Me": Migrant Women's Access to Protection for Family Violence in Belgium (New York: Human Rights Watch, 2012), www.hrw.org/report/2012/11/o8/law-was-against-me/ migrant-womens-access-protection-family-violence-belgium.

${ }^{28}$ UDHR, art. 14(1) ("Everyone has the right to seek and to enjoy in other countries asylum from persecution.”). Cf. Organization of American States, Montevideo Convention on Political Asylum (December 26, 1933), www.refworld.org/docid/4f3d180az.html (providing a regional right to asylum); D. Acosta, "Free Movement in South America: The Emergence of an Alternative Model?" Migration Information Source (August 23, 2016), www.migrationpolicy .org/article/free-movement-south-america-emergence-alternative-model.

29 Ramji-Nogales, "Undocumented Migrants" at 725-727. 
While human rights law claims to be universal in its scope and applicability, it fails in some cases and refuses in others to speak to the rights that are crucial in protecting undocumented migrants. International human rights law has not strayed far from its roots; the continuities with colonial rule are unmistakable. The rights contained within the human rights canon obscure the underlying assumption that all humans have equal autonomy and access to justice. Those who have been rendered less than autonomous through global economic inequality and the legacies of colonialism - undocumented migrants being just one example - fall outside the scope of protection. Human rights law is unmistakably silent on the question of how to protect these populations.

\section{HUMAN RIGHTS LAW'S SILENCES}

The protection gap that human rights law constructs and obscures creates an opportunity for migrant destination states to flex their sovereign muscle through a variety of mechanisms to prevent the undocumented from reaching their borders. ${ }^{30}$ These deterrence-based border control policies perhaps unsurprisingly do not prevent migrants from undertaking their journey, but instead amplify the dangers that migrants face in transit. Although human rights protections against mistreatment and abuse may apply in theory, migrants in transit are rarely able to enforce those rights. Without the right to enter, transit safely, or remain, the undocumented are subject to harsh treatment at the hands of states and private actors. Moreover, the images of hundreds of migrants approaching the borders of destination states in the Global North make ideal fodder for nationalist politicians seeking to expand their own power through xenophobic fearmongering.

For at least the past twenty years, migrant destination states have pushed their border enforcement well beyond their physical borders through programs such as the "Pacific Solution" in Australia and "Fortress Europe," as well as lesser-known programs such as Programa Frontera Sur in the United States and Mexico. Australia has been the most successful at preventing migrants from crossing its borders, effectively "stopping the boats" as its nativist politicians promised as part of their campaign platforms. This cruel policy began in 2001, when the Norwegian freighter, the MV Tampa, rescued more than four hundred Afghanis and Iraqis who had traveled by sea from Southeast Asia to seek asylum in Australia. ${ }^{31}$ The Australian government refused to allow these asylum seekers to land on Australian territory, instead unloading them into a naval vessel that transported them to the remote

$3^{\circ}$ For a comprehensive treatment of the topic, see D. FitzGerald, Refuge beyond Reach: How Rich Democracies Repel Asylum Seekers (Oxford: Oxford University Press, 2019).

${ }^{31}$ C. Inglis, "Australia: A Welcoming Destination for Some," Migration Information Source (February 15, 2018), www.migrationpolicy.org/article/australia-welcoming-destination-some. 
island of Nauru. There, the Australian government was able to detain these migrants in an asylum processing center they had previously created.

These detention centers, as well as similar centers in Manus Island, have been the subject of criticism by human rights treaty actors and academics. ${ }^{32}$ The analysis is telling: "offshore processing" is "neither explicitly prohibited nor authorized under the Refugee Convention and its Protocol and the relevant human rights treaties." 33 Although the treatment of migrants in detention centers violates human rights law, it has been difficult for migrants to enforce those rights given their distance from Australian territory and precarious status. ${ }^{34}$ The detention centers were briefly closed down by the Labor Party when it took power in 2007, but then reinstated in 2012 after sea arrivals began to increase. ${ }^{35}$ In the 2013 election, candidate Tony Abbott campaigned on a "stop the boats" slogan that ushered him into the prime ministerial suite. ${ }^{36}$ Using methods that afforded no deference to human rights law, such as turnbacks and towbacks, migrants arriving by boat have been returned to their home countries. ${ }^{37}$ As an island nation, Australia has ensured that undocumented migrants, including refugees, cannot enter their territory. Human rights law's gaps in protections, in this case the absence of a right to safe transit or entry, enable states to engage in extraterritorial processing. Moreover, though some existing human rights might offer some protections to undocumented migrants on paper, migrant vulnerability creates substantial obstacles to enforcing those rights.

Europe has also undertaken an array of programs to prevent migrants from reaching its borders. Regional human rights law has played an important role; though it has not established a right to entry, the European Court of Human Rights has held that member states exercising jurisdiction outside of national territory must process individual migrants' claims to protection before returning

${ }^{2}$ B. Doherty, "Affront to Human Rights': Top UN Official Slams Australia's Offshore Detention," The Guardian (September 10, 2018), www.theguardian.com/law/2018/sep/11/ affront-to-human-rights-top-un-official-slams-australias-offshore-detention.

33 M. Gleeson, "Protection Deficit: The Failure of Australia's Offshore Processing Arrangements to Guarantee 'Protection Elsewhere' in the Pacific" (2019) XX International Journal of Refugee Law $1-49$ at 4 .

34 Ibid., at 4, 10; United Nations High Commissioner for Refugees, Submission by the Office of the United Nations High Commissioner for Refugees on the Inquiry into the Serious Allegations of Abuse, Self-Harm and Neglect of Asylum-Seekers in Relation to the Nauru Regional Processing Centre, and Any Like Allegations in Relation to the Manus Regional Processing Centre (November 12, 2016).

35 Inglis, "Australia"; Gleeson, "Protection Deficit" at 6; Andrew and Renata Kaldor Centre for International Refugee Law, University of New South Wales, "Offshore Processing: An Overview" (May 9, 2017), www.kaldorcentre.unsw.edu.au/publication/offshore-processingoverview.

$3^{6}$ A. Rourke, "Tony Abbott, the Man Who Promised to 'Stop The Boats', Sails to Victory," The Guardian (September 7, 2013), www.theguardian.com/world/2013/sep/o $/$ australia-electiontony-abbott-liberal-victory.

37 Kaldor Centre, "Offshore Processing." 
them..$^{3}$ Human rights law does not, however, prohibit member states from preventing migrants from reaching their jurisdictions. The European Union and its member states engage in capacity-building efforts with border guards in home and transit states, establish readmission agreements with countries of origin and transit, and create mobility partnerships that require states of origin and transit to sign onto border control reforms and readmission agreements in order to create temporary migration opportunities for a limited set of workers. 39 Though human rights actors have expressed concern with the manner in which these agreements are enforced and their potential for violating the rights of migrants, human rights law's silence around entry and safe transit creates the opening from which these policies can grow.

For at least forty years, the United States has prevented migrants from reaching its sea and land borders through a variety of externalization policies. In 1981, the Reagan administration signed an agreement with the Haitian government that enabled the US Coast Guard to interdict on the high seas boats carrying Haitians and push the passengers back to Haiti. ${ }^{40}$ Nearly ten years later, the US Supreme Court held that the Refugee Convention's nonrefoulement protections did not apply on the high seas, allowing the George H. W. Bush administration to push back Haitians without screening their claims to refugee status. ${ }^{41}$ Since 1994, interdicted migrants have been detained at the US naval base in Guantánamo, Cuba; at times they have been screened for refugee status and at times they have simply been held awaiting return to Cuba or Haiti. ${ }^{42}$ On land, the US government has allocated substantial resources toward ensuring that Mexican authorities prevent Central American migrants from arriving at its southern land border. ${ }^{43}$ Through the Mérida Initiative and Programa Frontera Sur, the Obama administration provided financial and logistical assistance to Mexican border enforcement. ${ }^{44}$ Under the

$3^{8}$ Hirsi Jamaa and Others v. Italy, Eur. Ct. H.R., App. No. 27765/o9 (Grand Chamber, February 23, 2012).

39 Report of the Special Rapporteur on the Human Rights of Migrants, François Crépeau, pp. 14-17, U.N. Doc. A/HRC/23/46 (April 24, 2013); Communication from the Commission to the European Parliament, the European Council, the Council and the European Investment Bank on Establishing a New Partnership Framework with Third Countries under the European Agenda on Migration, $\mathrm{COM}(2016) 3^{85}$ (June 7, 2016).

$4^{\circ}$ B. Frelick et al., "The Impact of Externalization of Migration Controls on the Rights of Asylum Seekers and Other Migrants" (2016) 4 Journal of Migration and Human Security 190-220 at 199; Interdiction Agreement Between the United States of America and Haiti, 33 U.S.T. 3559 (September 23, 1981).

${ }^{41}$ Sale v. Haitian Centers Council, 509 U.S. 155, 187 (1993).

$4^{2}$ Frelick et al., "The Impact of Externalization" at 199-200.

43 C. Ribando Seelke and K. Finklea, U.S.-Mexican Security Cooperation: The Mérida Initiative and Beyond (Washington, DC: Congressional Research Service, 2016), pp. 6-8.

44 A. Castillo, The Mexican Government's Frontera Sur Program: An Inconsistent Immigration Policy (Council on Hemispheric Affairs, 2016), www.coha.org/wp-content/uploads/2016/10/ The-Mexican-Government\%Ez\%80\% g9s-Frontera-Sur-Program-An-Inconsistent-ImmigrationPolicy.pdf. 
Remain in Mexico program and the Asylum Cooperative Agreement, the Trump administration pushed some migrants back into Mexico to await their court hearings and sent others to Guatemala to pursue their claims for protection. ${ }^{45}$ Without a right to safe transit or entry under international law, domestic governments can interpret human rights law's silences to enable their externalization policies, with harsh consequences for the migrants subject to those policies. ${ }^{6}$

\section{FILLING THE SILENCES WITH MIGRANTS' VOICES}

Despite its claims to universality, international human rights law does not adequately reflect the interests and preferences of undocumented migrants. Without key rights relating to movement, namely, the rights to safe transit, entry, and to remain, migrants suffer substantial vulnerability and face serious obstacles to accessing the human rights to which they are ostensibly entitled. Destination states are able to leverage human rights law's silences to implement increasingly harsh measures to prevent migrants from even reaching their borders. By inflicting inhumane harms on humans on the move, these methods of border externalization also degrade the humanity of the societies the migrants seek to enter. Human rights law's colonial roots prevent it from fulfilling its potential as a project of emancipation.

An emancipatory approach to international human rights law might instead take the human seriously, beginning from the perspective of the law's subject: the migrant. A reimagined canon would identify and foreground the voices of those in precarious situations, asking what protections are needed to minimize their vulnerability. Those inquiries might well lead to a right to safe transit, entry, and to remain, but an emancipatory response must rest on empirical study to catalogue and uplift the migrant's perspective. This challenging task has yet to be performed, though several scholars are developing thoughtful and robust methods to collect migrant voices. ${ }^{47}$

45 K. M. Nielsen, Policy Guidance for Implementation of the Migrant Protection Protocols (January 25, 2019), www.dhs.gov/sites/default/files/publications/19_0129_OPA_migrant-protec tion-protocols-policy-guidance.pdf; Agreement between the Government of the United States of America and the Government of the Republic of Guatemala on Cooperation Regarding the Examination of Protection Claims, 84 Federal Register No. 224 at 64095-64099 (November 20, 2019).

$4^{6}$ A. Isacson, "I Can't Believe What's Happening - What We're Becoming": A Memo from El Paso and Ciudad Juárez (Washington, DC: The Washington Office on Latin America, 2019); Fact Sheet: Is Guatemala Safe for Refugees and Asylum Seekers? (Washington, DC: Human Rights First, 2019).

47 H. Crawley et al., Destination Europe? Understanding the Dynamics and Drivers of Mediterranean Migration in 2015 (Coventry: MEDMIG, 2016), www.medmig.info/researchbrief-destination-europe.pdf; G. Sanchez, "Critical Perspectives on Clandestine Migration Facilitation: An Overview of Migrant Smuggling Research" (2017) 5(1) Journal on Migration and Human Security 9-27. 
The year 2020 seems perhaps an unlikely juncture from which to demand radical reform in favor of the interests of undocumented migrants. As destination states sink to new depths of inhumanity toward humans on the move, one might reasonably argue that any changes to international law are more likely to diminish rather than expand the rights of migrants. Yet contemporary attitudes and policies toward migrants foreground the urgency of a response that underscores the humanity of the undocumented. Moreover, the unsettled political ground on which destination states currently stand can create unexpected openings, perhaps as citizens of these countries begin to realize the cost of inhumane border enforcement for migrants and for their own societies.

Although the governments of destination states may be unlikely in the current political climate to sign a multilateral human rights treaty that represents migrant interests, several other paths to generating a new set of migrant-centered human rights standards present themselves. Regional human rights bodies and other regional organizations might offer a location that is more amenable to migrant interests. In December 2019, the Inter-American Commission on Human Rights adopted the Inter-American Principles on the Rights of All Migrants, Refugees, Stateless Persons, and Victims of Trafficking, taking a first step in this direction. ${ }^{8}$ Cities may also provide a space for generating human rights standards, whether binding or expressive, that represent the interests of migrants. ${ }^{49}$ Other groups, from civil society to transnational social movements, might also seek to expand the source of human rights law beyond the state. Though a catalogue of rights generated by one of these groups will obviously not be binding law, it could offer a starting point for reframing perceptions of migrants and their rights through a process that rejects the state-centered focus of international law. Diaspora, transnational families, and others can similarly invoke conceptions of human rights that more clearly track the interests of migrants, either by adopting instruments and definitions created by other groups or by drafting their own language to represent the interests of their friends and loved ones. These groups and others, perhaps even including corporations and religious figures, could help to push forward a new framing of migrants' rights, which could be used to help persuade and remind citizens of destination states of the humanity of those on the move. It is a daunting road, but only by hearing and uplifting the voices of undocumented migrants can we push human rights law closer to its emancipatory potential, redeeming the humanity of migrants and citizens of destination states alike.

$4^{8}$ Comisión Interamericana de Derechos Humanos, Principios interamericanos sobre los derechos humanos de todas las personas migrantes, refugiadas, apátridas y las víctimas de la trata de personas, December 7, 2019, Res. 04/19, www.oas.org/es/cidh/informes/pdfs/Principios DDHH migrantes - ES.pdf.

49 C. Lasch et al., "Understanding 'Sanctuary Cities" (2018) 59 Boston College Law Review $1703-1773$. 
